\title{
Grundtvig, Bede and the testimony of antiquity
}

\author{
By S. A. J. Bradley
}

History offers any generation models of both continuity and discontinuity. Awareness of the testimony of continuities reaching back into antiquity is a powerfully conditioning cultural force, a means of interrogating the past for present answers and pointers to the future - as can be illustrated by an example of attitudes to the idea of a Christian ministry of women reaching back through such theologians as Grundtvig, Thomas Aquinas and the Venerable Bede to the early Church Fathers. In this light, it is a revealing exercise to consider attitudes to antiquity held by Grundtvig and the Venerable Bede whose Ecclesiastical History was among Grundtvig's earliest reading in Anglo-Saxon literature. Grundtvig proves to share much with Bede, not only in an awareness of the symbolic contemporary relevance of anecdotes from antiquity but in a certain perception of the deeper structures of historical record, from which both scholars elicit a Christian philosophy of history. It has been plausibly suggested that Grundtvig's ideas of universal history were crucially influenced by his encounter with the Anglo-Saxon poem Beowulf; but beyond the poetically embodied philosophy of Beowulf lies the universal-historical exposition of Bede, well known to Grundtvig. It would repay Grundtvig-scholars to explore more thoroughly Grundtvig's encounter with Bede as a primary part of his wider encounter with AngloSaxon culture, the more fully to understand the remarkable dynamic of Grundtvig's relationship to antiquity.

History, we know, is made up of continuities and discontinuities. Some people, when they are making use of history - whether as historians, or as theologians, or politicians, or just as individuals trying to make sense of the record of their own life - will choose to stress the continuities, linking the present to the past; sometimes, perhaps, linking modernity to antiquity. Others will choose to stress the discontinuities. Some, for example, will emphasise the discontinuities of Renaissance and Reformation, choosing for a variety of possible reasons to place a prior emphasis upon new beginnings. Others find a direct path across Reformation and Renaissance back to antiquity, and make of it a road they can freely travel, transporting along it, perhaps, from the past into the present, things they find valuable from antiquity and early tradition.

We all know that human nature, the human intellect, the imperatives of communal living and so on, being what they are, total discontinuity in the course of human affairs is inconceivable. The old saying is a truism: There is nothing new under the sun. But the freedom to choose to emphasise continuities, or alternatively dis- 
continuities, is one of the most valuable licences we permit ourselves in organising our understanding of the records of human affairs. Both my subjects made free, though principled and purposeful use of that licence.

For Bede, it was in the continuities of history, from Scriptural times to his own day, that great truths were to be discovered. Grundtvig too, it may be thought, was one who chose to seek and build a philosophy upon the continuities of history from out of antiquity. Not all faithful sons of the Reformation have been as willing as he to rediscover the overgrown paths leading backwards into antiquity. For some of them, to do so would be as though the people that had walked in darkness had indeed seen a great light - but had then gone back poking about in the old shadows, in the foredoomed delusion that there they might find things worth bringing back into the light. Not so Grundtvig?

I will come back to all this shortly; but I would like to move on into my topic by mentioning what struck me, when I read of it, as a remarkable example of a relevant continuity (within Christian tradition) - and indeed of a conscious sense of that continuity in the people involved.

In his book Så fjern og dog så noer (Høirup 1991, 165-166) Henning Høirup tells of the ordination of the first three women priests in Denmark in Skt Knuds Kirke in Odense on 28 April 1948.

According to his account, there were only two bishops who at that time (as he put it) "went in for women priests". They were Hans Øllgaard, Bishop of Fyn 1938-58, and Axel Rosendal, Bishop of Roskilde 1935-53. Both of them, Høirup points out, were "grundtvigske biskopper" (bishops adhering to Grundtvig's concept of the Church). Bishop Øllgaard conducted the ordination. Høirup writes:

I was present, and I shall not forget his address - upon the Easter gospel, where the angel at the grave ordained the women, dispatched them with the proclamation of Jesus' resurrection: "Fear not! for I know that it is Jesus the crucified you seek. He is not here: for he is arisen as he has said - make haste away and say to his disciples that he is arisen from the dead (Høirup 1991, 165-166).

The two grundtvigske bishops, Øllgaard and Axel Rosendal, the only ones who went in for female priests, could refer to the master's [loerefaderens] - that is, Grundtvig's - great poem: Christenhedens Syvstjerne [The seven stars of Christendom]. Here he prophesies that in the sixth congregation, the Nordic, people would learn to understand that woman shall not be consigned to merely hearing, but can also conduct the Word of the Lord - like the Lord's Mother and like the women at Christ's tomb who were entrusted with bearing witness to the arisen one: 
Han, som Paaske-Morgenrøde,

Først for Kvinderne oprandt!

Han Marie Magdalene

Sendte ud med Livets Ord!

Hvem tør Kvinderne formene

Vandringen i hendes Spor!

$[\ldots]$

Først, naar atter fromme Kvinder

Som i Ordets Heltetid

Herren tjene som "Bispinder",

Bruge Tungerne med Flid,

Saa faar Hjertet Mund og Mæle ${ }^{1}$

[He, like Easter's rosy dawning, / to the women first appeared! / He Maria Magdalena / with the Word of Life sent forth! / Who then dares deny that women / in her steps should follow on! / [...] / First when once more pious women, / as in the Word's Heroic Age / serve the Lord as his Bispinder, / busily employ their tongues, / then shall heart gain mouth and language.]

Høirup points out that "Bispinder" (plural form of the conventional Danish designation of a bishop's wife) is set in inverted commas, and in Grundtvig's usage here means not "wives of bishops" but "tilsynskvinder" - superintendent women, priests.

Grundtvig, however, was by no means the first to argue on the basis of this Gospel account that a remarkable acknowledgement of the ministry of faithful women was signalled when Christ chose to reveal his resurrection to the world through the women who went to tend to his body in the tomb.

If we step backwards down that road into antiquity and early tradition, beyond the Reformation and Renaissance to Thomas Aquinas, and to his Expositio in Mattheum [Exposition of Matthew], and his commentary upon the visit of the Marys to the sepulchre of Christ on the first Easter morning, we can find a very similar view to that which the grundtvigske biskop, Hans Øllgaard, following Grundtvig, preached in his sermon that day in 1948.

We find there in Aquinas the exclamation: Felices feminae quae triumphum resurrectionis mundo annuntiare meruerunt! (Aquinas 1953) - O blessed women, whose deserving it was to announce to the world the triumph of the resurrection. "Quae meruerunt" - "whose deserving it was" or more simply "who merited". But nor is Aquinas the first to pay this homage to those faithful and ministering women: he is here simply quoting a yet more ancient authority, still further back down the road into antiquity, into the tradition of the early Church. He is expressly quoting - with proper explicit acknowledge- 
ment by name - from the commentary upon the Gospel of Matthew by the Anglo-Saxon scholar, Bede the Venerable, early in the eighth century.

Bede, who in turn drew many of his ideas from the writings of Gregory the Great, Apostle to the English, and from the Fathers of the Church more widely, makes much of this concept that these women meruerunt - merited - to be those who should announce to the world the good news of the resurrected Christ: not the disciples, who were lying low in this darkest of all hours, but the women, the Marys, who, says Bede in so many words, were determined to minister - even in death - to him whom, living, they had loved. Their merit lies in this capacity to fulfil the debt of love even in the direst adversity, to follow not the head which rationalised death as a finality and which calculated the dangers, but to follow the heart and to remain faithful to the loved Lord in his death as they had been in his life.

So archetypal (for him and his sources) is the faith, love and duty of the Marys that Bede goes on expressly to make these women, bearing spices, hastening at dawn to the sepulchre of Christ, the allegorical type of all faithful Christian souls hastening towards the grave (that is, towards their own corporeal death) with the offerings of their faith, their love and their good works - where they too will share in the triumph of the resurrection achieved for them by Christ.

I don't doubt for a moment that if Grundtvig read this text, Bede's exposition of the Gospel of Matthew, he recognised Bede as his soulmate, in this understanding of, and celebration of, a Christian ministry of fromme Kvinder, pious women.

I wish I could now dramatically produce the evidence that Grundtvig did indeed read this text; but to be honest, I cannot think it was likely. Pretty certainly it is some other tradition of exegesis Grundtvig is drawing upon. Until the publication of J. P. Migne's Patrologia Latina ${ }^{2}$ between 1844-55, few of Bede's writings were readily accessible to any but the most assiduous scholarly researcher. ${ }^{3}$

For my present purposes, however, this is no fatal flaw. First, I wished simply to offer this case as a rather striking example of a dynamically active cultural continuity: in this case, the potent and effectual continuity of a particular interpretation of a Christian text, which we can trace backwards from modernity to antiquity; from the first ordination of Danish women in 1948 overseen by two "grundtvigske biskopper", through Grundtvig's Christenhedens Syvstjerne, beyond the Reformation and Renaissance to Thomas Aquinas and so back to the Venerable Bede's commentary upon Matthew and the traditions of the early Church of which he was an orthodox transmitter. But secondly I wish in the rest of this paper to make the case that even if Grundtvig did not know this particular text, he certainly knew other writings of Bede where Bede expresses the 
same esteem for a ministry of Christian women in the annals of northern Christendom; and much more than this: Grundtvig's encounter with this Anglo-Saxon scholar provided him with other good grounds for recognising in Bede a soul-mate, whose authority consolidated his own sense of what was true and right, and affirmative of crucial continuities in the life and especially in the Church of the Northern peoples, as attested in the historical record. Again, in short, we are here in the company of Grundtvig the medievalist, with his sensibilities attuned - in a way not exactly typical of his generation to the rich significations of the traditions of the early Church.

There can surely be no doubt of Grundtvig's esteem for Bede. Christian Sigfred Ley ${ }^{4}$ tells a little story concerning Grundtvig's eldest son, Johan. When Johan was quite small he liked to come into his father's study of an evening, around the time when the lamps were being lit, and to play spelling games with him. (Ley, a sentimental fellow, may be romanticising what for Johan could well have been a more intimidating ritual). One evening, Grundtvig had a visitor, Frederik Ludvig Bang Zeuthen who was at that time a young admirer of Grundtvig and a faithful member of his congregation at Vor Frelsers Kirke, but who later grew dismissive of Grundtvig because so Zeuthen felt, interestingly in our present context - Grundtvig was more a spokesman for Danish antiquity and archaic Christianity than a significant contemporary preacher and theologian. Curiously enough, on that evening, when little Johan (says Ley) came bounding into his father's study undeterred by a visitor's earnest presence, it was not to ask for a spelling game but to recite something he had undertaken to learn by heart - a piece of Den danske Rimkrønike [The Danish Rhyming Chronicle].

"I've got it now!" exclaimed Johan. "Really?" said Grundtvig. "Let me hear it then." So Johan began: "Det siger Beda, den cerlige Mand ..." [This Bede declares, that right honest man]. But alas - maybe it was after all the presence of Zeuthen - a few lines into the recitation Johan dried up; and so, says Ley, he had to go away and learn it all over again.

The text which Johan had so hoped to recite to his father's satisfaction was something like this:

Thet syer Beda then ærilighe man

Thet ær well gjort i hwo thet kan ath skriffuæ forælderes gerningher allæ

Ere the ondæ man maa them fly

Ere the godæ man maa them thy

och engælunde fraa them fallæ

[This Bede declares, that right honest man: / it is well done of him who can / to write down all his forebears' deeds. / If they be evil, 
them we must shun; / if they be worthy, grant them respect / and lapse not from them, howsoever]

The lines derive from (and are here transcribed from the preface of) Den danske Rimkrønike [The Danish Rhyming Chronicle], published as Denmark's earliest printed book in the Danish language by Gotfred af Ghemen (Copenhagen 1495). The medieval Danish author appears to have known quite well Bede's Ecclesiastical History of the English People, ${ }^{6}$ since he is summarising quite accurately what Bede wrote in his preface to that work - which, incidentally, Bede addressed to his king, Ceolwulf, who had actively patronised his work. ${ }^{7}$ Bede writes:

Should history tell of good men and their good estate, the thoughtful listener is spurred on to imitate the good; should it record the evil ends of wicked men, no less effectually the devout and earnest listener is kindled to eschew what is harmful and perverse, and himself with greater care pursue those things which he has learned to be good and pleasing in the sight of God (McClure-Collins 1999, 3).

From the Rimkrønike then, if from nowhere else, Grundtvig would have known of Bede and his traditional status as one of the western Fathers of History. But also those books which Grundtvig began to consult in 1815 when he decided to teach himself Anglo-Saxon in order to read the newly published text of Beowulf in the original tongue - they all advised him that in Bede he was likely to find things of the greatest concern to himself. I am thinking particularly of the edition by Franciscus Junius (Junius 1655) of the poetry attributed to Cædmon; and of the monumental Thesaurus compiled by George Hickes and Humphrey Wanley (Hickes Thesaurus, 1703-05). We know from the protocols of the Royal Library and from his own testimony that he consulted these works, and indeed that he found and used an edition of Bede's Ecclesiastical History in both its Latin and its Old English (or Anglo-Saxon) versions by Abraham Wheloc (Cambridge, 1644).

In due course, in 1864, Bede's Ecclesiastical History was translated into a modern Danish version; not by Grundtvig himself but certainly with his encouragement and under his guidance, by Christian Malta Kragballe (Kragballe 1864). Kragballe, echoing Grundtvig, commends the work because it charts the highway by which Christianity came into the North. But well before this it also appears to have got into the folk-highschools in one form or another. After Peter Rørdam visited Rødding school in 1847, he reported back to Grundtvig that he had audited several lectures including one by the new principal, Frederik Helveg, upon the reception of Christianity by the Anglo-Saxons. This can only have been based, whether directly or indirectly, upon Bede's narratives.

I have elsewhere spoken and written upon the great impact made 
upon Grundtvig by his encounter with Bede's chapter on the beginnings of English Christian poetry with Cædmon at Whitby, at some date before 680 - a highly consequential example of Grundtvig's appropriation of antiquity and early tradition. He also took story-lines from Bede as inspiration for his own didactic references in his poetry and his songs: for example, that of the famous conversion of King Edwin at York in 627, and that of the seventh-century Anglo-Saxon missionaries including Willibrord, who went forth carrying Christianity and Christian learning into the former homelands of their people, to Frisia and the Lowlands, and into Germany. ${ }^{8}$

Perhaps most importantly of all, as I shall argue shortly, Grundtvig pretty surely found in Bede the most remarkable endorsement for the philosophy of history which was forming in his own mind over the decade in which he made his major encounter with Bede.

Before I proceed further, however, I should perhaps acknowledge that not all will necessarily know with any instant familiarity who this Bede was. I will therefore sketch in an impression of him.

Bede was born, probably in 672 , in a settlement somewhere on the estates of the then quite newly founded monastery of WearmouthJarrow near the estuaries of the rivers Wear and Tyne respectively, in Northumbria (though located in two separate sites, it was a single monastery). At the age of seven he was entrusted to the care of Ceolfrith, abbot of the monastery, for his education. He spent the whole of his life there, apart from visits to Lindisfarne and York, and there he died in 735. However, the founder of the monastery, Benedict Biscop, was also its lavish patron. From frequent journeys through Gaul and Italy to Rome in the 670s and 680s he brought back sacred relics, paintings on boards, stone-masons, glaziers and even the Archcantor John from Rome to teach Gregorian chant - but also a wealth of books which came to form a library of great distinction; and on the foundation of this library Wearmouth-Jarrow became a centre of learning with Bede as its greatest scholar. ${ }^{9} \mathrm{He}$ in turn, over a lifetime's teaching which continued almost to the very hour of his death, numbered some six hundred monks among his pupils.

He was himself the author of some forty-five books. These included Scriptural and patristic commentaries, which he regarded as his chief work - and whereby, incidentally, he helped lay the foundations of that easy familiarity with patristic writings (the writings of the Fathers of the Church) which my colleague Donald (A. M.) Allchin and I have often commented upon as a remarkable characteristic of the poetry of the Anglo-Saxons and the early Celtic Christian world. Along with these commentaries he also wrote studies on time, the reckoning of time, chronology and history (Bede is largely responsible for the western Church's adoption of the system of dating the year 
from the Incarnation of Christ); historical biographies; collections of homilies, hymns and poems in Latin and in English; studies in grammar and rhetoric; a martyrology; translations; and letters.

The work by which Bede is best known today is his Historia ecclesiastica gentis Anglorum - The Ecclesiastical History of the English People. In the preparation of this great work which he completed in 731 he commissioned searches of the archives of Rome, and collected and collated documents and testimonies from trustworthy informants in Canterbury, York, Lindisfarne, Iona and other places.

The Anglo-Saxon Boniface, Apostle to the Germans, writing home to England on hearing of Bede's death in 735, called him candela ecclesiae quam illuxit Spiritus Sanctus - the light of the Church whom the Holy Spirit illumined. Early on, copies of his work were acquired for the pontifical library in Rome - where some of them are still to be seen. When, in the last quarter of the ninth century, King Alfred embarked upon his great educational programme by ordering the translation from Latin into English of all those books which it was most needful for men to know (Alfred's words), Bede's Ecclesiastical History was naturally included, and took on an additional new life in the vernacular (English) language. Bede's significance as a teacher of orthodox Christian doctrine was recognised by Dante who, in the Paradiso placed him in the Fourth Sphere, in the company of such as Isidore of Seville and Thomas Aquinas. ${ }^{10}$ In the later Middle Ages Thomas Aquinas repeatedly cited Bede as an authority on a par with the other great doctors of the universal Church. And indeed, albeit belatedly, in 1899 Leo XIII formally named Bede Doctor of the Universal Church, to join such as Jerome and Augustine.

There are still hundreds of manuscripts of Bede's work surviving from all over Europe, indicating the huge circulation his writings had from his own day onwards over the following six or seven centuries. One can take it for granted that works by Bede were to be found in the medieval monastic libraries of Denmark. It is no surprise that the author of the medieval Danish rhyming chronicle, which Johan and Svend were required to learn by heart, ${ }^{11}$ should know of Bede and should choose him as the authority to pronounce upon the moral usefulness of history.

So much then for Bede's life's work and his high repute over 1200 years and more. But what could Grundtvig have found in Bede's Ecclesiastical History that we might believe was congenial to his own thinking, during those years 'in the study' (1815-22), and the years of his visits to England (1829-31), and the years during which he absorbed what he had encountered, and put it to use back home in Denmark?

Perhaps the first thing which anyone approaching this work 
acknowledges is that it is a quite remarkable statement of national identity; and more than that, it is a remarkable example of how to construct a national identity. Grundtvig could hardly have missed this (to him) congenial and useful aspect of the work. England in the seventh and eighth centuries was politically fragmented, but from as early as 731 onwards it had, in Bede's Historia, a national history written in elegantly lucid Latin prose which would continue for centuries to act as an inspiration to national endeavours. The late eighth- or early ninth-century manuscript London, British Library MS Cotton Tiberius C. II whose first page is reproduced as the cover design to McClure-Collins (1969) clearly displays the title - a title which must have caught the attention of any nineteenth-century reader who was interested in Herder's ${ }^{12}$ nineteenth-century ideology of das Volk: Its title, I remind you, is Ecclesiastica historia gentis Anglorum. The ecclesiastical history of the English gens or Volk/Folk/folk.

So here was this identity-defining history of a gens or Folk which had for the most part migrated from that region which was to become so painfully precious to Grundtvig - Slesvig, Angeln. But what (we may ask with Grundtvig, if we imagine him reading his way through Bede's narratives), what if not political cohesion, enabled Bede to bestow upon these people the unifying title of gens Anglorum? What bound them together with each other, and with the Saxons and Jutes who had migrated with them?

Their common language and cultural background were of course essential factors. But supremely above all else, it was, in Bede's reading and construction of history, their oneness within the Christian Church. This is Bede's overarching theme, as his title makes plain: cohesion within one national congregation, in orthodox unity with the greater family of the historical and universal Church.

We can hardly doubt that this was revelatory reading for Grundtvig. Here are the oldest surviving written annals of a Northern people, long preceding Snorri and Saxo, and what do they present to such a reader as Grundtvig? They present the national identity of a Northern folk in terms of a national congregation drawn into one by the Holy Spirit working through the early Church.

As one would expect of such an account of such a period in European history, the great majority of Bede's players in the great drama of conversion and apostasy and ultimate triumph of the English Church within the English nation are men; but it should also be said (in support of a claim I made earlier) that anyone reading the History is also likely to be struck by the role Bede records for women, both secular and religious, in what he chose to present as the triumph of Christianity in Britain. When he narrates the conversion of Kent, he mentions that one Christian woman was there in Canterbury, already witnessing to her faith, before the arrival of Augustine and the mission 
from Rome. She was the queen Berhta, wife of Ethelbert king of Kent. She was a daughter of the Frankish royal house and, already being a Christian, was permitted under the marriage agreement to follow her own religion in heathen Kent. She appears to have used an old building left by the Romans as her chapel, now St Martin's Church in Canterbury, so this church was ready and waiting for Augustine's use when he came to begin his work of converting king and people. Similarly, when Bede narrates the conversion of Northumbria at York in 627, he gives much space to the role played by Æthelburh (Book II; especially ch. 9; McClure \& Collins 1999, especially 84-87) daughter of Aethelbert of Kent and his queen, and wife of Edwin king of Northumbria. Bede quotes (McClure \& Collins 1999, 89-91) a letter sent from Pope Boniface V (elected pope December 619, died October 625 ) asking for Æthelburh's assistance in the great task of converting the king and the nation to Christ. "Pour into his mind," Boniface urges her,

a knowledge of the greatness of the mystery which you have believed and the wonder of the reward which, by the new birth, you have been accounted worthy to receive (...) Then the testimony of holy scripture will be clearly and abundantly fulfilled in you: The unbelieving husband shall be saved by the believing wife. ${ }^{13}$

Grundtvig, faithful to Bede's order of things, also puts Æthelburh in the same prior position, in his song on King Edwin at York:

Jeg førte ret et Konge-Liv

I York, mit Herre-Sæde,

Og Adelborg, min Ægte-Viv,

Hun var min Hjertens-Glæde.

Hun kom fra Syd, hun kom fra Kent,

Med Bisp og Bog i Følge,

Og aldrig kunde jeg det nænt,

Sin Tro hun skulde dølge.

Tro hvad du vil! vær mig kun tro!

Elsk lidt mig, elsk mig længe!

Det var vor Tale, begge to,

Hvor Blomster groe i Enge! ${ }^{14}$

[I led a truly kingly life / in York, my royal seat, / and Æthelburh, my wedded wife, / she was my heart's delight. // She came from the south, she came from Kent / with bishop and book in train / and never could I have desired / that she should hide her faith. // Believe what you will, but be true to me! / Love me little, love me long! / This was the talk of the two of us / where flowers bloom on the ings! ${ }^{15}$

Similarly again (to return to Bede) he records that once Christianity had been established among the English, women continued to feature 
who were pre-eminent in their spirituality: women who, for example, transposed their maternal nature into the wise and sympathetic motherhood of a religious community - as Hild at Whitby. Hild was the daughter of King Edwin's nephew. With Edwin and all the royal household she had listened to the preaching of Bishop Paulinus in 627 and had been baptised by him in a specially constructed oratory among the decayed Roman grandeur of the city of York. Choosing the religious life rather than diplomatic and dynastic marriage she was eventually appointed abbess over a joint community of nuns and monks at Whitby on the north-east coast overlooking the North Sea. There, writes Bede:

After the example of the primitive church, no one was rich, no one was in need, for they had all things in common and none had any private property. So great was her prudence that not only ordinary people but also kings and princes sometimes sought and received her counsel when in difficulties (Book IV, ch.XXIII; McClure \& Collins 1999, 211).

She required all under her authority above all to study the Scriptures and to give time to the performance of good works. Many were ordained as priests, and no less than five were eventually elected to be bishops in such sees as York, Dorchester and Hexham.

In Hild, Bede, with sympathy and sensitivity, recognises - and invites us (and Grundtvig, as he reads) to recognise in her - a Christian ministry fulfilled. Despite her warrior-name, she is no Brynhild whose distinction was to excel in manliness. Her maternal nature she adapted to spiritual motherhood. All who knew her called her 'Mother' says Bede, and he makes it abundantly clear that her spiritual children were many. When Bede comes to tell the momentous story of the beginnings of Christian poetry in the English language, with Cædmon at Whitby, it is as a story illustrative of what Hild, Cædmon's abbess, delivered into the life of the English Church that he presents it. As we have already seen, it was an attitude towards Christian womanhood which Bede had long since defined by the time he came to write his Historia Ecclesiastica.

In Bede, then, was available to Grundtvig testimony not only of the Christian antiquity of the Northern poet or skjald but also of the Christian antiquity of Northern womanhood: for Bede would surely have agreed with Grundtvig that a church without women would be like a beechwood bare of leaves. ${ }^{16}$

Now however we need to move on a stage further, and recognise that the five books and 140 chapters of anecdotes and narratives in the Ecclesiastical History tell more than a mere organisational account of the first 130 years of the English Church. As the story of Cædmon itself so vividly illustrates, Bede's ever-present thesis, whether 
explicitly articulated or not, is that from the conversion onwards indeed even before the conversion while the English people still walked in darkness - the Holy Spirit was at work amongst them. The English were an earmarked nation - a chosen people. Bede rests a philosophy of history upon the assumption that history reveals the providential purposes and interventions of God within the world of his creation. Grundtvig - the Grundtvig who was simultaneously absorbed in the legend history of the Scylding dynasty (in Beowulf), the Grundtvig in whom ideas of the folkelige were taking shape, and no less the Grundtvig who would seek to reconcile the mythic visions of his Northern forebears with the Christian revelation - will have understood what Bede was talking about.

Consider Bede's oft-cited account of the moment at which Gregory was inspired to bring about the conversion of England to Christ, when he saw some English boys offered for sale as slaves in Rome. ${ }^{17}$

In terms of Bede's philosophy of history, it is no merely lucky coincidence that the nation from which these boys came had a name which could be punningly connected with the Latin word angelus, 'angel" 18 - eventually giving rise to the famous tag "Non Angli, sed angeli"; nor that the name of their homeland, Deira, ${ }^{19}$ enabled Gregory to say that this nation deserved to be saved de ira, from the wrath of the Day of Judgment; nor that their king's name should be $Æ l l e,{ }^{20}$ enabling Gregory to promise that one day a triumphant Alleluia would be sounded there. Bad puns they may well seem to us; but to the early medieval mind they were characteristic tokens of God's providential purposes, embedded in the very mother-tongues of the Church and of the English people. Therefore Bede does not neglect - in quite a different part of his History - to record that when Augustine first entered the city of Canterbury in the first stage of the conversion of the English people he and his monks came singing that Alleluia! prophesied by Gregory and preordained by God.

Likewise, when later on the Christian king Oswald won a crucial battle over the combined forces of heathens and apostates in Northumbria, fighting like Constantine under the sign of the Cross, it was no mere lucky coincidence that the battle-site straddling the Roman wall in the hills above Hexham was already named from time immemorial, long before the decisive battle, Heofonfeld, Heavenfield (McClure-Collins 1999, 111-112). It is still so called today; and incidentally - such is the appeal of antiquity - a great wooden cross is still maintained at the roadside and a church still stands on the site consecrated before Bede's lifetime to commemorate the great victory of the Church Militant in England.

All these, within Bede's philosophy of history, were tokens of the providential purposes of God, given far ahead of the fulfilment of these purposes within the course of human affairs. 
For Bede, however, the testimony of history goes further still. It was not merely lucky coincidence that he found that he could trace patterns in the history of the gens Anglorum which parallelled the history of the Chosen People of the Old Testament or mirrored in this latter day some event in the life of Christ. This was not invention; it was discovery. History was not the random record of a welter of discontinuities. History revealed continuity. And just as the cohesion which formed the gens Anglorum was religious and spiritual, so the cohesion which formed the Historia, the history of the English, was a recognition of the providential and sacred in the course of worldly events - with its template in the interacting narratives of the Old and New Testaments.

The discovery of such parallels or the discovery of repeating patterns in history - as is very evident, for example, in the lives of saints such as Bede's favourite saint, Cuthbert, or in the story of Oswald going into a decisive battle like Constantine under the sign of the Cross - are actually taken as affirmations of the truth of the event which is found to have had its prefigurations in earlier history. In a sense, the past is always latent in the present. And similarly, the discernment of such patternings in history made it possible to understand more clearly the options for the future. In the light of such discernible patterns of history, the Church might better understand how it should dispose itself, a king how he should govern, a people how they should live their communal life under God; and so on. In this sense, then, the present, far from being a finite and discrete moment in the linear progression of time, entails not only memory of the past and anticipation of the future, but some kind of active engagement with past and future, which transcends the strictly rational understanding of time and chronological sequence.

As must now be plain, the Bede whom Grundtvig encountered around 1815 was not exclusively an historian (in a modern sense), any more than Grundtvig himself was exclusively an historian (in a modern sense). For Bede, the study and teaching of history was a part - a major part, but only a part - of a single greater mission, to teach the truth and the truths of the Christian faith as held by the Christian Church through the ages. This might be done by exposition of the Scriptures, by theological argumentation, by discussion of the liturgy of the church, by composing hymns and promoting hymnology, and by composing poetry (Bede engaged in all of these) - or by searching history for evidence of the guiding hand of God revealing itself amidst the ongoing struggle of good against evil and life against death. In such terms as these, we may already be thinking, Bede and Grundtvig are clearly enough fellow-spirits among the ranks of Christian teachers, even though eleven hundred years separate them. For both, historiography is a polemical undertaking and for a Christian the 
polemic must be Christian polemic. I quote:

Is it in fact improper in a Christian, when he writes a Brief Outline of World History, first and foremost to consider from a Christian standpoint the relationship of peoples and writers with Christianity, and to judge this according to the clear word of the Bible? ${ }^{21}$

These are Grundtvig's words as he looked back in 1823-24 upon his work of the preceding decade: a Christian historian will naturally seek to demonstrate the truth of the Christian revelation and the workingout of the Biblical blueprint for this temporal world.

So, then, we may begin to see what challenging and encouraging ideas lay there for Grundtvig to discover, when he began reading in this earliest history of the Christian establishment among the Northern peoples. All this, I feel persuaded, he draws upon in a major act of 19th-century cultural appropriation (or reception).

Before I come to my final point, I have to make a very brief excursion away from the Latin prose writings of Bede into AngloSaxon vernacular poetry. In his book Grundtvigs historiefilosofi, Ole Vind says:

In Grundtvig's view Anglo-Saxon poetry wove the history of the North into universal history, in that it effected a connection between the classical world - and Christendom - around the Mediterranean and the history of more recent times along the northwest European coasts, and, significantly, by weaving in the historical poesy of the North with the universal-historical course of poesy. [...] Grundtvig's whole universalhistorical view is precisely tied in to the history of poesy throughout the ages, with its point of departure in the Hebrews' divine revelation in poesy and mythology. Only against this background does one understand how important Anglo-Saxon poetry in general and Beowulf in particular, came to be for Grundtvig. ${ }^{22}$

Vind's evaluation of Grundtvig's philosophy of history has proved controversial and I don't wish to involve myself here in the broader debate. But as regards Grundtvig's use of Anglo-Saxon antiquity in forming his philosophy of history I am thus far in admiring agreement with him. And of course I am pleased to see such appreciation of Grundtvig's Anglo-Saxon encounter regaining its ground in Grundtvig scholarship. There is little doubt in my mind that in Grundtvig's various interpretations and evaluations of the poem Beowulf in particular - in his articles in Danne-Virke, his introductions to Bjovulfs Drape (1820) and to his critical edition Beowulfes Beorh (1861) - he is consolidating a certain understanding of the nature of history on the basis of the philosophy of history which he is quite accurately (and sensitively) eliciting from that poem.

Since this paper is supposed to be about Grundtvig and Bede rather than Grundtvig and Beowulf. I can't allow mvself to go into anv 
lengthy exposition of the Beowulf-poet's philosophy of history. Instead I will make just a couple of very brief assertions about the poem in order to establish what I (and other students of Anglo-Saxon literature and culture) see as an ideological affinity between the poet of Beowulf and Bede.

The poet, like Bede, makes both explicit and implicit assertions of an historical perspective upon the story he is telling. There is for example the explicit assertion which the poet, commenting upon his own story, makes in his own voice: God still rules the world as he always did. The course of human affairs is acted out, for good and for ill, under the eyes and hand of God. There are also various examples of implicit assertions - of which this is one example: The poet constructs a continuity between the earliest Scriptural history - the story of Cain and Abel - and the present time of the story of Beowulf in Denmark. Because the monster Grendel is declared to be descended from Cain, Beowulf's fight with him is implicitly the latest episode in an ongoing struggle throughout human history - under the eyes of God and beneath God's providential hand.

Rightly, in my view, Ole Vind insists:

[Grundtvig's] new orientation [ = towards England, away from the crude and disparaging characterisation of England in Europa, Frankrig og Napoleon (1815)] cannot be understood, with Thaning, as the consequence of a profound conversion in 1832, immediately after the journeys to England, but has emerged from an interest over many years in Anglo-Saxon poetry, combined with the dream of creating a universal-historical scholarship. Following the Beowulf-immersion ${ }^{23}$ in the summer of 1815 the significance of the Anglo-Saxons in Grundtvig's view of history had been steadily growing - at the same time as the memory of England as hereditary foe from 1807-1814 had been modified. In 1832 the Anglo-Saxons had thus become the central turning-point in both world-history and church-history. In Kirke-Speil Grundtvig mentions it explicitly as "An extraordinary thing which especially for us Danes must seem notable and not to be forgotten, that it was first through the discovery of Beowulf that it eventually became clear that "there had come to pass in England a great marvel"." ${ }^{24}$

Certainly it is Beowulf and not Bede that Grundtvig discusses at considerable length and at intervals over his life - between 1815 and 1820 and again in connection with the editions of Beowulf and the reissue of his paraphrase of the poem. It was after all Beowulf that had been put on the agenda by Thorkelin in 1815; and through all the following years it was Anglo-Saxon poetry in the Anglo-Saxon language which engaged Grundtvig the would-be editor, Grundtvig the hymnwriter, Grundtvig the translator of the great folke-krøniker of the North ${ }^{25}$ - and indeed increasingly engaged the international scholarly world. Ole Vind is right enough in observing the priority of nlace Beowulf has as the subiect of Grundtvig's nublished 
engagements with an Anglo-Saxon philosophy of history.

Vind is also alert to Grundtvig's high estimation of Bede:

Grundtvig speaks of how, in the midst of the darkness of the Middle Ages, a light delightfully showed forth in that great island where, with the Anglo-Saxon Church-Father Bede from Northumberland, there arises "a little Anglo-Saxon mother-church and prototype school for Germany and for the North". ${ }^{26}$

As a particular instance of what Grundtvig found in Anglo-Saxon literature which eventually contributed to his estimation of the Anglermenighed in Christenhedens Syvstjerne (1860) Vind picks very appropriately upon the figure of Cædmon:

In so far as Grundtvig was especially captivated by the poet Cædmon is due, among other things, to the fact that Bede depicts him as originally being an ordinary man from among the folk, who in a dream was called by God to be a Christian poet. ${ }^{27}$

This is all surely right, and all well-observed - as far as it goes. But it is my contention now, on such grounds as I have here set out, that Grundtvig students would do well to look beyond the individual discrete anecdote - of Cædmon or Hild or of Edwin - to that whole Anglo-Saxon philosophy of history, that whole universal-historical context in which the Venerable Bede sets the story of Cædmon and sets the whole history of the establishment and early evolution of the English congregation.

For the inspiration of those underlying ideas that form Grundtvig's remarkable and distinctive understanding of both world history and church history, it is surely first and foremost to his encounter with Bede and especially with that first Church-history of the North which the Venerable Bede's Ecclesiastical History constitutes, that Grundtvig students need to be looking, before they turn to examine its more poetic and legendary articulation in Beowulf.

I am aware that this paper has not presented any new hard evidence which future scholars would find it impossible to ignore. But I hope as I have steadfastly hoped in all my work on Grundtvig's engagement with the poetry of the Anglo-Saxons - that I may have helped to call attention back to Grundtvig's lifelong affair with Anglo-Saxondom, and to a field which we know Grundtvig and some of his immediate followers very extensively cultivated, but which modern Grundtvig scholarship has tended to let lie fallow.

If we are to understand the legacy of Grundtvig as fully as is possible, we of course need to know what Grundtvig knew, read what he read, try as best we can to react as he reacted. And if, by doing so, we are confirmed in a belief that antiquity and tradition can still speak to us as profitably it spoke to Grundtvig, maybe - especially in these 
days when there is much talk of threats to our cultural heritage and traditional values - maybe we would do well to remind ourselves what this heritage actually is and these values actually are. Then we may judge whether it is still true that antiquity can speak to us - as it emphatically did to both Bede and to Grundtvig. Then we may decide whether continuities matter to us any more, whether antiquity is still valuable to us or whether it is merely, so to speak, old history.

\section{Appendix}

\section{Bede's account of Gregory's resolution to convert the English to Christianity; from the Ecclesiastical History, Book II, ch, 1 (McClure-Collins 1999, 70-71)}

We must not fail to relate the story about St Gregory which has come down to us as a tradition of our forefathers. It explains the reason why he showed such earnest solicitude for the salvation of our race. It is said that one day, soon after some merchants had arrived in Rome, a quantity of merchandise was exposed for sale in the market-place. Crowds came to buy and Gregory too amongst them. As well as other merchandise he saw some boys put up for sale, with fair complexions, handsome faces, and lovely hair. On seeing them he asked, so it is said, from what region or land they had been brought. He was told that they came from the island of Britain, whose inhabitants were like that in appearance. He asked again whether those islanders were Christians or still entangled in the errors of heathenism. He was told that they were heathen. Then with a deep-drawn sigh he said, "Alas that the author of darkness should have men so bright of face in his grip, and that minds devoid of inward grace should bear so graceful an outward form." Again he asked for the name of the race. He was told that they were called Angli. "Good," he said, "they have the face of angels, and such men should be fellow-heirs of the angels in heaven." "What is the name," he asked, "of the kingdom from which they have been brought?" He was told that the men of the kingdom were called Deiri. "Deiri," he replied, "De ira! good! snatched from the wrath of Christ and called to his mercy. And what is the name of the king of the land?" He was told that it was Ælle; and playing on the name, he said, "Alleluia! the praise of God the Creator must be sung in those parts." So he went to the bishop of Rome and of the apostolic see, for he himself had not yet been made pope, and asked him to send some ministers of the word to the race of the Angles in Britain to convert them to Christ. He added that he himself was prepared to carry out the task with the help of the Lord provided that the pope was willing. But he was unable to perform this mission, because although the pope was willing to grant his request, the citizens of Rome could not permit him to go so far away from the city. Soon after he had become pope, he 
fulfilled the task which he had long desired. It is true that he sent other preachers, but he himself helped their preaching to bear fruit by his encouragement and prayers. I have thought it proper to insert this story into this Church History, based as it is on the tradition which we have received from our ancestors.

\section{Abbreviations}

GSV I-VI: Th. Balslev et al. (eds) (1944-64), Grundtvigs Sangvaerk, vol. 1-6, Copenhagen.

$H V$ I-III: N. F. S. Grundtvig (1833-43), Haandbog $i$ VerdensHistorien, bind 1-3 (pr. in US VI-VII).

Hickes Thesaurus: George Hickes (1703-05), Linguarum Veterum Septentrionalium Thesaurus Grammatico-Criticus et Archaeologicus, Oxford.

KS: N. F. S. Grundtvig (1871), Kirke-Speil eller Udsigt over den christne Menigheds Levnetsløb (pr. in US X).

Kvinde-Evangeliet: N. F. S. Grundtvig (1842), "Kvinde-Evangeliet", published in Nordisk Tidsskrift for christelig Theologi udgivet af Th. W. Oldenburg Præst og P. Chr. Kierkegaard Lic. Theol., IV, 514, Copenhagen.

$S V$ : Sang-Værk til den danske Kirke II (1870).

US: I-X: Holger Begtrup 1904-09 (ed.), Nik. Fred. Sev. Grundtvigs Udvalgte Skrifter, vol. 1-10, Copenhagen.

$V U$ : Georg Christensen \& Hal Koch (1940-49) (eds), N. F. S. Grundtvig Vaerker i Udvalg, vol. 1-10, Copenhagen.

\section{Bibliography}

\section{Works by Grundtvig}

Balslev, Th. et al. (eds) (1944-64), Grundtvigs Sang-Vark, vol. 1-6, Copenhagen.

Begtrup, Holger 1904-09 (ed.), Nik. Fred. Sev. Grundtvigs Udvalgte Skrifter, vol. 1-10, Copenhagen.

Christensen, Georg \& Koch, Hal (1940-49) (eds), N. F. S. Grundtvig Varker i Udvalg, Vol. 1-10, Copenhagen.

Grundtvig, N. F. S. (1833-43), "Haandbog i Verdens-Historien", vol. $1-3$, in US VI-VII.

Grundtvig, N. F. S. (1842), "Kvinde-Evangeliet" in Nordisk Tidsskrift for christelig Theologi udgivet af Th. W. Oldenburg Præst og P. Chr. Kierkegaard Lic. Theol., IV, 5-14, Copenhagen; GSV III, 402. Grundtvig, N. F. S. (1871), "Kirke-Speil eller Udsigt over den christne Menigheds Levnetsløb" in US X.

Johansen, Steen \& Høirup, Henning (eds) (1948), Grundtvigs Erindringer og Erindringer om Grundtvig. Conenhagen. 


\section{Works by other authors}

Aquinas 1953: Corpus Thomisticum. Sancti Thomae de Aquino: Catena aurea in quatuor Evangelia ; Expositio in Matthaeum a capite XXVI ad caput XXVIII. Textum Taurini 1953 editum ac automato translatum a Roberto Busa SJ in taenias magneticas denuo recognovit Enrique Alarcón atque instruxit. Cited from online text at http://www.corpusthomisticum.org/cmt26.html (March 2006).

Colgrave, Bertram \& Mynors, R. A. B. (eds) (1969), Bede's Ecclesiastical History of the English People, Oxford.

Hickes, George (1703-05), Linguarum Veterum Septentrionalium Thesaurus Grammatico-Criticus et Archaeologicus, Oxford.

Høirup, Henning (1991), Så fjern og dog så noer, Herning, Denmark.

Junius, Franciscus (ed) (1655), Caedmonis monachi Paraphrasis poetica Genesios ac praecipuarum sacrae paginae historiarum, Amsterdam.

Kragballe, Chr. (1864), Angler-Folkets Kirkehistorie af Beda den Arvardige. Paa Dansk med Indledning og Anmoerkninger af Chr. M. Kragballe, Copenhagen.

McClure, Judith \& Collins, Roger (eds) (1999), [Bertram Colgrave's translation of] Bede: The Ecclesiastical History of the English People, Oxford.

Vind, Ole (1999), Grundtvigs historiefilosofi, Copenhagen.

\section{Notes}

This article is based upon a lecture given in the Centre for Grundtvig Studies, University of Aarhus, in March 2006, on the theme of Grundtvig and antiquity.

$1 \quad$ From Den Nordiske Menighed ( $V U$ VI, 344-345). Grundtvig also gave Mary Magdalena the title of Apostelinde ['Apostle-woman'] (KvindeEvangeliet (1842), 7; GSV III, 402): I Paaske-Morgenrøden / Hun fandt ved Graven Trøst; / Om Seier over Døden / Først tones hendes Røst! // Lyksalig var den Kvinde, / Paa første Paaskedag, / Hun blev Apostelinde / For Guds Apostel-Lag! [In Easter's rosy dawning / at grave she solace found; / and of that victory over death / her voice was first to speak! // Blissful was that woman / on that first Easter Day, / Apostle-woman was she / to God's Apostle-band].

2 Patrologiae Latinae Cursus Completus was published in two series totalling 217 volumes (1844-55), plus four volumes of indices (volumes 218-221, 1862-64). Migne assigned to the works of Bede volumes 90-95 of the Patrologia.

3 At this time, apart from a copy of Abraham Wheloc's edition of Bede's Ecclesiastical History, mentioned below, the Royal Library Copenhagen appears to have owned books containing other pieces by Bede including Franciscus Maria Florentinius. Vetustius Occidentalis Fcclesice Marturo- 
logium (Lucae 1668), containing Bede's Martyrology; and Helias Putschius, Grammatica Latince auctores antiqvi (2 vols, Hanoviae 1605), containing some of Bede's writing on Grammar.

4 Danskeren IX, 1893, 4 (Johansen-Høirup, 132); the anecdote presumably relates to the later 1820 s or very early 1830 s, since Johan was born on 14 April 1822.

5 Laura Grundtvig, wife of Svend, in Minder fra gamle grundtvigske Hjem I, Copenhagen, 1921, 44-50 (Johansen-Høirup 1948, 146-147) records that "the objective of the rhyming chronicles - in a pleasurable way to fix in the memory what was communicated orally - was, for Svend's part, completely achieved. He learned them by heart with great enjoyment, and those of them which as a boy he had found particularly amusing and beautiful he still knew by heart in his old age".

6 See Colgrave-Mynors 1969 (Latin text) and McClure-Collins 1999 (English translation).

7 Though I make nothing of it here, it is worth noting that in a variety of ways and on various occasions Grundtvig too presented himself directly and indirectly to his king as mediator and didactic interpreter of the history of the Danish kings and the Danish people, in the lineage of Suhm, Langebek, Snorri and Saxo; and his role was recognised and rewarded with a royal stipend and grants.

8 Notably in Christenhedens Syvstjerne (1860) and Sang-Vark til den Danske Kirke II (1870).

9 "Bede's own writings, when analysed for the sources which he drew upon, give an indication of the enormous range of books available in the monastic library in his day, the fruits of Biscop's Contintental journeys" (McClure-Collins 1999, xi-xii). Dante, Paradiso Canto X:130 f.

See notes 4 and 5 .

J. G. Herder (1744-1803), author of Ideen zur Philosophie der Geschichte der Menschheit, 1784.

131 Corinthians $7: 14$; in the King James Bible: "For the unbelieving husband is sanctified by the wife."

14 Kong Edvin in SV II, no. 107 and in GSV II, 301. The text was first published in 1842 in the augmented second edition of Krønike-Riim (with altered subtitle: til Levende Skolebrug med Oplysninger [for vital schooluse with informative notes; where, in keeping with Grundtvig's educational philosophy, 'vital' has the sense of 'living, life-asserting' in opposition to 'dead, moribund, deadening']).

15 The choice of 'ings' is irresistible here: it is a Danish loan-word into the Yorkshire dialect, though usually reserved for meadows along the river bank.

16 I Taare-Bække! rinder / Kun stride over Støv, / For Kirken uden Kvinder, / Som Lunde uden Løv! [You rivulets of tears flow / impetuous over dust [i.e. the mortal cheek] / for Church devoid of women / as glade devoid of leaf!] (Kvinde-Evangeliet, 1842, 12; GSV III, 407).

17 See the Appendix to this article.

18 "He was told that they were called Angli. 'Good,' he said, 'they have the face of angels, and such men should be fellow-heirs of the angels in 
heaven'." (McClure-Collins 1999, 70). Of course, the series of solemn puns proceeds better in the Latin.

19 The southerly division of Anglo-Saxon Northumbria, with its capital in York.

20 Ælle, then king of Deira, was father of Edwin who finally led the Northumbrians to Christian conversion in 627.

21 From a draft of an unpublished text, Apologia for Christianity, 1823-24; US IV, 229-235 (Johansen-Høirup 1948, 63).

22 "Den angelsaksiske digtning flettede i Grundtvigs syn Nordens historie ind i universalhistorien, idet den udgjorde et forbindelsesled mellem den klassiske verden - og kristendommen - omkring Middelhavet og den nyere tids historie ved de nordvesteuropæiske kyster, og vel at mærke ved at flette Nordens historiske poesi ind i poesiens universalhistoriske forløb [...] Grundtvigs hele universalhistoriske syn [er] nøje knyttet til poesiens historie gennem tiderne, med udgangspunkt i hebræernes guddommelige åbenbaring i poesi og mytologi. Kun på den baggrund forstår man, hvor vigtig den angelsaksiske digtning $\mathrm{i}$ almindelighed, og Beowulf $\mathrm{i}$ særdeleshed, blev for Grundtvig" (Vind 1999, 174).

23 Beowulf-rusen; the noun rus here, as in Grundtvig's own coinage Asarusen, signifies 'intoxication' and is used to characterise his state of intensive immersion in Beowulf issues and in the myths of the Norse gods.

24 "Den nyorientering kan ikke med Thaning forstås som følge af en dybtgående 'omvendelse' i 1832, umiddelbart efter Englandsrejserne, men er fremgået af den årelange interesse for angelsaksisk digtning forbundet med drømmen om at skabe en universalhistorisk Vidskab. Siden Beowulf-rusen i sommeren 1815 havde angelsaksernes betydning $\mathrm{i}$ Grundtvigs historiesyn været stedse voksende - samtidig med, at mindet om England som arvefjenden fra 1807-1814 fortonedes. I 1832 er angelsakserne så blevet det centrale omdrejningspunkt $\mathrm{i}$ både verdenshistorien og kirkehistorien. I Kirke-Speil nævner Grundtvig det direkte som en 'Besynderlighed, der især for os Danskere maa være mærkværdig og uforglemmelig', [footnote: US 10, 189 (KS 1871)] at det først var gennem opdagelsen af Beowulf, at der efterhånden blev klart, at 'der i Engelland var sket et stort aandeligt Underværk' [footnote: US 10, 190 (KS 1871)].” (Vind 1999, 317-18).

25 The three 'folk-chronicles' of the North (Nordens Folke-Krøniker) were Saxo's Latin Gesta Danorum, the Anglo-Saxon poem Beowulf and Snorri Sturluson's Icelandic Heimskringla (sagas of the Norse kings) which Grundtvig translated during his "years in the study" (1815-22), partly to reassert ancient Danish identity and Nordic communality after loss of Norway 1814, partly in spirit of opposing, as in his periodical DanneVirke, "all the Germanising here at home" (Gr).

26 "Grundtvig taler om, at der midt i middelalderens mørke blev dejlig lyst på den store $\varnothing$, hvor der med den angelsaksiske kirkefader Bede fra Nordhumberland [sic] opstår 'en lille Angel-Sachsisk Moderkirke og Mønsterskole for Tydskland og Norden' [footnote: US 7, 536 (HV III, 1843)] - før Karl den Stores tid." (Vind 1999, 316).

"Når Grundtvig var særlig optaget af skialden Kadmon. skvldtes det 
blandt andet, at han hos Beda skildres som en oprindelig jævn mand af folket, der i drømme blev kaldet af Gud til kristelig skjald" (Vind 1999, 318). 